\title{
Hubbul Waton Minal Iman as Reinforcement Theorem of State Defense in the Context of Terrorism Prevention in Indonesia
}

\author{
Slamet Tri Wahyudi ${ }^{1 *}$ \\ ${ }^{1}$ Faculty of Law, Diponegoro University, Semarang, Indonesia
}

\begin{abstract}
A series of suicide bombing terror in Surabaya and Sidoarjo a few days ago drew public attention. It was because the perpetrator was a family. After being investigated, the motive of the suicide bomber was based on false religious doctrine. According to the confession of the perpetrator's children who survived, they had been indoctrinated by religious doctrine and living in a closed environment. Terrorism uses the teachings of Islam as justification for its actions. Therefore, the policy for the prevention of terrorism should also include the Islamic values. The main cause of radicalism effect development is the faded sense of nationalism and love of the country. State defense approach is considered appropriate as a form of prevention against terrorism. The state defense values can enhance the sense of nationalism and love of the country. However, state defense approach will not be effective without involving religious approach because the root of terrorism issues in Indonesia is based on the mistakes in understanding religion, therefore, the most appropriate way is integrating state defense approach with a religious approach based on the spirit of hubbul waton minal iman. Spirit hubbul wathon minal iman can be the antithesis on the meaning of mujahid.
\end{abstract}

\section{Introduction and literature review}

Attack on terrorist inmates in Command Headquarters of Mobile Brigade of Depok and a series of suicide bombings happened in police stations in Surabaya and Sidoarjo, as well as attack on police officer in Regional Police of Riau showed that the main target of the attacks of the terrorist groups was not only to cause fear but also to be aimed at the police institution. The hatred of the terrorist groups towards the police officers was very reasonable, considering the action of Anti-Terror Special Detachment 88 in thwarting any terror acts. Besides, Special Detachment 88 managed to capture and paralyze leaders of international terrorist networks (including Amrozi, Imam Samudera, Dr. Azhari, Santoso, Aman Abdurrahman, etc.).

Based on the inventory data from 2000 to 2014, the terrorism crime in Indonesia initially symbolically only targeted the interests of America, the West, and their allies. It was

*Corresponding author: dayuning86@gmail.com 
evidenced by the bombing attacks of Bali I and II, JW. Mariott hotel, Australian embassy in Kuningan, Ritz Carlton hotel, and others. Subsequently, these groups also targeted government, in this case Regional Government, Indonesian National Army (TNI), and especially Indonesian National Police (Polri), as their main enemy since it was considered as thogut government which has hindered their goals so far. The proven facts included Regional Government robbery, planning of assassination of President Susilo Bambang Yudhoyono in Cibubur, and attacks on police stations in Purworejo and Kebumen, Central Java, resulting in the death of 3 (three) police officers [1].

Essentially, the growing effect of radicalism and the number of terrorism acts were caused by the faded sense of nationalism and devotion toward the state. When one does not love his/her state anymore, he/she will be vulnerable to be affected by radical ideology. Take for example, the bombing terror happening in Surabaya and Sidoarjo. Based on the results of the investigation of the police, the intellectual actor behind the suicide bombing was Dita (who was none other than a suicide bomber). After being traced, it turned out that Dita had a track record as an activist who often demonstrated in supporting the establishment of an Islamic state with Khilafah ideology and rejected Pancasila as the National principle.

If examined from the case, it turned out that there was relevance that when one does not love his/her state anymore, it is possible that one day he/she will be a terrorist bomber, even as a suicide bomber. Therefore, in the effort to counter terrorism, the state defense approach must be used since the state defense values can foster a sense of nationalism, devotion, and pride to the state. In addition, if examined more deeply, suicide bombings are mostly carried out by Muslims. Thus, the effort to foster the devotion toward state is not enough with the values of the state defense, but also must be based on the devotion toward state derived from Islamic values namely hubbul waton minal iman.

The terrorist propaganda in spreading its effect by giving mujahid (whoever fights in the way of Allah SWT will go to heaven) proved to be effective in recruiting cadres ready to be suicide bombers. This condition cannot be allowed since if it is ignored it will be the same as justifying the view of jihad fi sabilillah that has been believed by terrorists so far.

\subsection{Overview of The Doctrine of State Defense}

Most of the Indonesian people assume that radicalism and terrorism are enemies of Police and TNI. This assumption is not true because in fact, the responsibility to protect and defend the state is the responsibility of all Indonesian citizens. Preventing the radicalism and terrorism is an obligation for all Indonesian people, even an integral part of the national duty [2].

The state defense becomes a new perspective to describe citizens' devotion toward their homeland, nation, and country. Substantially, the state defense can be reflected in all citizen behavior that always feels the devotion for their homeland until the end of their life defending their nation and country from the threats of attacking enemies [3]. Basically, the state defense is nationalism spirit containing motivation to become an independent and sovereign nation. The state defense is understood as an attitude, character, and deed that always try to fight and defend various symbols and state institutions to be able to exist in the midst of global threats [4].

In a theoretical perspective, the state defense is an effort to foster the spirit of nationalism and patriotism in all citizens' community to defend their country against enemy threats [5]. State defense is always an obligation for every citizen because the country consists of citizens who are in mutually beneficial reciprocal relations with the state [6]. In general, state defense programs are needed by every country because enemy threats always haunt a country [7].

The state defense must be understood in a broad context. Every citizen is an entity living in a state building so that citizens are essentially obliged to establish, maintain, and protect 
every regulation, institution, and state apparatus. The state must be defended to the point of death if the state can be trusted in running its government. There is no reason for citizens to evade and avoid the obligation to defend their state. Citizens must be submissive, loyal, obedient, and subject to every regulation made by the state in an effort to promote the state defense [8].

The state defense is a regular, comprehensive, integrated and sustainable determination, attitude, and actions of citizens based on the devotion toward homeland and awareness in the nation and state. For Indonesian citizens, the effort to defend the state is based on the devotion toward homeland and awareness in the nation and state of Indonesia, with a belief in Pancasila as the National principle and based on 1945 Constitution as the state constitution. The embodiment of efforts to defend the state is to sacrifice in order to maintain independence, state sovereignty, and unity and integrity of Indonesian nation, integrity of archipelago and national jurisdiction, as well as Pancasila and 1945 Constitution values [9].

\subsection{Overview of the Doctrine of Hubbul Waton Minal Iman}

Hubbul waton minal iman literally can be interpreted as devotion toward homeland is a part of iman. The meaning of the devotion toward homeland that has been understood so far is devotion toward state, wholeheartedly and is willing to sacrifice to the last drop of blood. In the Islamic concept, the devotion toward the state is not only interpreted as an embodiment of the devotion toward state, but more than that there is an attachment between love and a belief in one's own iman in God (Allah SWT).

Basically, hubbul waton minal iman is not a hadith or Quran verse, but is a formulation from KH. Wahab Asbullah aimed to awaken the nationalism spirit in fighting against the invaders. The birth of hubbul waton minal iman concept was motivated by the occurrence of a conflict between nationalism and religious spirit since it was ridden by political interests. Then, there was a clash of tribes, races, and religions (SARA) utilized by certain parties, in this case, the bearer group of the Islamic state spirit who wanted to establish a Khilafah state in Indonesia.

The fruit of the thought of hubbul waton minal iman is the birth of a jihad resolution initiated by Hadratus Syeikh KH. Hasyim Asyeeari (founder of Jamiyah Nahdlatul Ulama). Hadratus Syeikh KH. Hasyim Asy'ari stated that maintaining the existence of The Unitary State of the Republic of Indonesia (NKRI) from all things that threaten it must be carried out by Muslims, not solely in the name of nationalism, but for the survival of Muslims living in the state, and so that the glory of Islam and the rise of its shari'a in the colonial countries will not be achieved. The essence of defending the state and nation is a form of nationalism and devotion toward religion. The existence of the defense toward homeland becomes a form of defense toward religion. In other words, defending the homeland is the same as defending the religion and war in the way of Allah SWT [10].

\section{Objective study}

With the above mentioned legal phenomenon, the author was interested in conducting research on counter-terrorism criminal acts connecting state defense approach and spirit of hubbul waton minal iman. Moreover, this research also wanted to explain the urgency of national jihad in fighting terrorism as an embodiment of state defense values and the spirit of hubbul waton minal iman. 


\section{Methodology}

This was a scientific paper in the field of law. Therefore, the method used was legal research [11]. Research is a scientific activity related to analysis and construction, which is carried out methodologically, systematically and consistently [12]. In this research, conceptual and philosophical approaches were used. The conceptual approach was carried out to construct an ideal concept about the state defense approach in counterterrorism, while the philosophical approach was carried out to explore the nature of state defense and the spirit of hubbul waton minal iman (love for the country is part of faith) as a source of value which is the foundation of counterterrorism. In this research, the writer conducted an interview with Prof. KH. Said Aqil Siradj. This interview was intended to find solutions in addressing the problems of terrorism and radicalism for the life of Indonesian people.

\section{Discussion}

\subsection{Alignment of State Defense Approach with Spirit of Hubbul Waton Minal Iman in Counter-Terrorism Criminal Acts}

The counter-terrorism in Indonesia is not the same as other countries. Its handling efforts are very careful. It is not only due to respect for human rights, but also because a small part of Indonesian society sympathizes and supports the terrorism movement. In their view, the terror act is believed to be a struggle form of jihad fi sabilillah justified by religion.

In its development, there are major problems that Indonesian government must realize in facing the terrorism threat that terrorism is able to manipulate religious teachings so as to attract sympathy and attention from young people, ranging from secondary to high education [13]. The manipulation of the religious teachings covers: first, justification of the terrorism acts by manipulating Quran verses, essentially justifying the terrorism acts in the form of violence acts and violence threats, through either suicide bombings or armed attacks on law enforcement officers, second calls for jihad fi sabilillah stating that anyone dying in the struggle to defend the religion of Allah will be guaranteed to go to heaven and has been anticipated by 72 angels.

The interpretation of religion to carry out violence based on religious spirit is a denial of true religious teachings. Narrow and partial interpretation used as legitimacy in carrying out the terror to spread fear and worry to other people or groups is called religious terrorism. The religious terrorism is a theoretical action based on religious values which tend to be misinterpreted, reduced, and misused to carry out the terror acts [14].

Misunderstandings in interpreting jihad as a physical struggle or armed resistance results in the emergence of radicalism giving birth to extreme actions. The terrorism acts have been going on are not jihad. Every Muslim is recommended for jihad, but do not interpret it as physical friction. Jihad is not terror and terror is not jihad. Jihad is not terrorism as it is echoed by West. There is no single Quran verse teaching terrorism. Even Islam strongly forbids behavior hurting and terrorizing others [15].

By looking at this reality, the state defense approach by arousing a sense of nationalism and fostering the devotion toward homeland and the state defense spirit will not be effective enough in facing the terrorism face in the name of religion. In an effort to counter the religious terrorism, the focus of its handling is to correct the misunderstanding in understanding religion. Consequently, a religious approach based on hubbul waton minal iman spirit is needed. Therefore, the government must involve religious leaders, especially moderate Islamic Community Organizations (such as Nahdlatul Ulama and Muhammadiyah) to correct the misunderstanding based on the guidance of Quran, Hadith, and Ijtima of Ulama. 
It is expected that after the emergence of thinking awareness about the truth in understanding the religion, the next task of the government is to continuously foster national insight with the aim that the terrorists can return to love their state. Thus, it is important to harmonize religious approaches originated from hubbul waton minal iman spirit and the state defense approach in the effort to counter the terrorism in Indonesia.

\subsection{Urgency of National Jihad Against Terrorism as an Embodiment of State Defense's Values and Hubbul Waton Minal Iman Spirit}

In the current context, jihad in defending the state becomes very relevant to be echoed again. It is because the danger posed by the radicalism and terrorism has threatened the state ideology, state security, and state sovereignty of Indonesian. Basically, national jihad is the embodiment of the state defense values and implementation of hubbul waton minal iman spirit. The national jihad can be interpreted as a struggle in defending the homeland wholeheartedly by sacrificing body and soul to preserve and maintain the integrity of The Unitary State of the Republic of Indonesia (NKRI).

The call that fighting the terrorism is a national jihad was expressed by Prof. K.H. Said Aqil Sirodj (General Chairman of Nahdlatul Ulama Executive Board). According to Prof. K.H. Said Aqil Sirodj, terrorism is the main enemy of Indonesian people. Thus, all elements of the nation, Police, TNI, and all of Indonesian people must unite in the struggle against terrorism and radicalism. He further stated that whoever fights in defending the homeland from the terrorism threat can be qualified as a mujahid, and if he/she dies while struggling in protecting and defending the state, he/she will be placed in the heaven of Allah SWT.

If examined, the statement is an antithesis to the meaning of mujahid which has been believed by terrorists so far that the terrorists who blew themselves up to jihad in defending the religion of Allah SWT is considered as martyrs and guaranteed to go to heaven. Topics related to jihad must be evaluated from the shari'a perspective to determine the actual law in religion. On this basis, martyrdom operations (amaliah istishhadiah) or at certain times referred to as suicide operations must be discussed from a religious perspective to avoid misunderstandings because these two terms are sometimes used together so it gives the impression that they are synonyms [16].

The debate about whether suicide bombing can be qualified as martyrdom operation (amaliah istishhadiah) or vice versa as suicide act (intihar) which is part of terrorism acts must be rectified. Basically, the suicide act has been prescribed in the Islamic religion, but it is limited to certain conditions, such as martial law (darul harbi). In the Palestinian war against Israel, Palestinian fighters carrying out suicide bombings to defend the state from the enemy attacks can be qualified as martyrdom operations (amaliah istishhadiah).

This is different from what is done by terrorist groups blowing themselves up with the aim of killing infidels in Indonesia. This self-detonation can be classified as a suicide act forbidden in Quran. It is because the suicide bombing carried out by the terrorists is not in a state of martial war (darul harbi). Furthermore, the suicide act cannot be justified since it is not used to defend the state and actually cause more destruction to the state. Hence, it can be concluded that the suicide act done by the terrorists is not a martyrdom operation.

\section{Conclusion}

In the effort to counter the religious terrorism, the focus of its handling is done by rectifying misunderstanding in religion. Hence, the government must involve religious leader figures, especially moderate Islamic Community Organizations (such as Nahdlatul Ulama and Muhammadiyah) to rectify the misunderstanding based on the guidance of Quran, Hadith, and Ijtima of Ulama. The national jihad is embodiment of the state defense values and 
implementation of hubbul waton minal iman spirit. The importance of affirmation of the national jihad emphasizes the existence of law enforcement officers (in this case, members of Special Detachment 88) killed in carrying out their counter-terrorism tasks. The existence of the national jihad is a strong encouragement and motivation for the law enforcement officials in their effort to protect and defend The Unitary State of the Republic of Indonesia.

\section{References}

1 D. Prasetyo, Ilmu dan Teknologi Kepolisian, "Implementasi Penanggulangan Terorisme dan Radikalisme di Indonesia”, p. 53-54 (Raja Grafindo Persada, Jakarta, 2016)

2 S. Harahap, Upaya Kolektif Mencegah Radikalisme dan Terorisme, p. viii, (Siraja, Depok 2017)

3 Schmidt, Theory of State, p. 84, (MacMillan Press, London, 2003)

4 M. Allen, Perception on State, p. 13, (Westview Press, New Hampshire, 2001)

$5 \quad$ R. Misbach, State and Nationality, p. 24, (Free Press, Oxford, 2006)

6 M. Mingst, The Filoshopy of Nationality and Identity, p.40, (Wesbrom Press, London, 2007)

$7 \quad$ W. Kline, Sojourn 4 23, (2009)

8 Subagyo, Bela Negara "Peluang dan Tantangan di Era Globalisasi", p.3 (Graha Ilmu Yogyakarta, 2015)

9 W. Widodo dkk, Pendidikan Kewarganegaraan, "Pengantar Teori", p. 227, (Andi Offset, Yogyakarta, 2015)

10 Yusrianto, In Right 3 2, (2014)

11 P. M. Marzuki, Yuridika 16 2, (2001)

12 S. Soekanto dan Sri Mamuji, Penelitian Hukum Normatif "Suatu Tinjauan Singkat", p.1, (Raja Grafindo Persada, Jakarta, 2006)

13 Zulfadli, Akademika, 22 1, (2017)

14 Kementerian Perencanaan Pembangunan Nasional Republik Indonesia, Rencana Kerja Pemerintah Tahun 2015: Buku II Prioritas Pembangunan Bidang, p. 6-10 (Kementerian Perencanaan Pembangunan Nasional Republik Indonesia, Jakarta, 2014)

15 K. Ghazali, Aksi Teror Bukan Jihad, p. 140, (Daulat Press, Jakarta, 2015)

16 M. Hanif Hasan, Teroris Membajak Islam "Meluruskan Jihad Sesat Imam Samudera dan Kelompok Islam Radikal”, p. 160, (Grafindo Khazanah Ilmu, Jakarta, 2007) 